\title{
PERSPECTIVE
}

\section{Light and inherited retinal degeneration}

\author{
D M Paskowitz, M M LaVail, J L Duncan
}

Br J Ophthalmol 2006;90:1060-1066. doi: 10.1136/bjo.2006.097436

Light deprivation has long been considered a potential treatment for patients with inherited retinal degenerative diseases, but no therapeutic benefit has been demonstrated to date. In the few clinical studies that have addressed this issue, the underlying mutations were unknown. Our rapidly expanding knowledge of the genes and mechanisms involved in retinal degeneration have made it possible to reconsider the potential value of light restriction in specific genetic contexts. This review summarises the clinical evidence for a modifying role of light exposure in retinal degeneration and experimental evidence from animal models, focusing on retinitis pigmentosa with regional degeneration, Oguchi disease, and Stargardt macular dystrophy. These cases illustrate distinct pathophysiological roles for light, and suggest that light restriction may benefit carefully defined subsets of patients.

See end of article for authors' affiliations

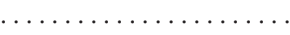

Correspondence to: Jacque L Duncan, MD, Beckman Vision Center, UCSF School of Medicine, San Francisco, CA 94143-0730, USA: duncanj@vision.ucsf.edu

Accepted for publication 1 May 2006 t was first suggested over a century ago that light exposure might modify the course of disease in patients with retinal degeneration, ${ }^{1}$ implying a possible therapeutic benefit of light deprivation. Four small studies have investigated this hypothesis in patients with retinitis pigmentosa (RP), a group of hereditary retinal dystrophies characterised by progressive photoreceptor degeneration, night blindness, visual field constriction, and electroretinographic (ERG) abnormalities, with rods affected earlier than cones. Berson ${ }^{2}$ used an opaque scleral contact lens to occlude one eye for 6-8 hours per day for 5 years in two young adults with RP. Progression of disease was symmetrical in both patients. ${ }^{2} \mathrm{~A}$ shorter trial using monocular sunglasses worn by three children with RP for 3 months also showed no protection.

A third report described a man with RP who had sustained trauma to the anterior segment of the right eye at age 7 , resulting in occlusion of the pupil by a thick membrane. Surgical correction and physiological testing 42 years later revealed that the retina had been protected by a $1.2 \log$ unit filter. Fundus examination and ERG offered no evidence that degeneration had been slowed in the occluded eye. ${ }^{3}$ In the fourth study, 13 RP patients wore a brown contact lens with low transmission on one eye for $1-3$ years. In eight patients, the rate of visual field loss was reported to be slower in the light restricted eye. ${ }^{4}$ However, other measures of visual function were not used, and these data await confirmation.

No benefit of light deprivation has been convincingly demonstrated in patients with RP.
However, the underlying genetic defect was not defined for any of the patients in these trials. It is now known that RP exhibits extraordinary genetic heterogeneity (http://www.sph.uth.tmc. edu/Retnet), and it remains possible that light deprivation could be beneficial for patients with certain mutations. This idea has received considerable support in recent years from animal studies. For some models of retinal degeneration, the progression of disease is indeed slowed by darkness, accelerated by bright light, or both. Several of these animal models carry mutations also found in patients.

Table 1 lists mammalian animal models of inherited retinal degeneration for which the effects of light have been assessed in peer reviewed studies. For three well characterised groups of models, the animal data are discussed in detail below, together with studies of patients carrying mutations in the corresponding genes. The literature on retinal damage by constant light in wild type albino rodents has been reviewed recently ${ }^{5}$ and will not be discussed further. Mutations that cause light dependent retinal degeneration in the fruit fly Drosophila melanogaster $^{7}$ are also outside the scope of this paper.

\section{AUTOSOMAL DOMINANT RP: RHODOPSIN MUTATIONS ASSOCIATED WITH REGIONAL DEGENERATION}

Rhodopsin (RHO) mutations are a common cause of autosomal dominant RP (ADRP), accounting for some $25 \%$ of families in the United States. ${ }^{7677}$ The change of proline to histidine at codon 23 (Pro23His, P23H) is found in the most common American mutant allele. ${ }^{35} 78$ Several mutations including $\mathrm{P} 23 \mathrm{H}$ cause a distinctive phenotype classified by Cideciyan and colleagues as class Bl. ${ }^{79}$ Typical features include slower progression and better visual function compared to other forms of ADRP; more rapid degeneration in the inferior than in the superior retina, correlating with earlier loss of the superior visual field; and delayed dark adaptation. ${ }^{79-90}$ However, some patients with the $\mathrm{P} 23 \mathrm{H}$ mutation have a more uniform distribution of relatively mild degeneration, possibly representing an early stage of disease. ${ }^{79}$

It has been proposed that the faster progression of disease in the inferior retina may result from a modifying effect of light. This argument

\footnotetext{
Abbreviations: $A D R P$, autosomal dominant retinitis pigmentosa; ERG, electroretinography; $N$-ret-PE, $N$ retinylidene-phosphatidylethanolamine; $R H O$, rhodopsin; $\mathrm{RK}$, rhodopsin kinase; RmP, rim protein; RP, retinitis pigmentosa; RPE, retinal pigment epithelium; STGD, Stargardt disease
} 
Table 1 Effects of light exposure on animal models of retinal degeneration

\begin{tabular}{|c|c|c|c|c|}
\hline Gene product (symbol) & Mutation & Species & Findings* & Human counterpart† \\
\hline \multicolumn{5}{|l|}{ Modified by light } \\
\hline Arrestin (Sag) & Knockout $^{8}$ & Mouse & $\begin{array}{l}\text { Protection by } \mathrm{DR}^{9} \\
\text { Exacerbation by light }\end{array}$ & Oguchi disease," ARRP ${ }^{12}$ \\
\hline $\begin{array}{l}\text { ATP/GTP binding protein } 1 \\
\text { (Agtpbpl, Nnal) }\end{array}$ & $\begin{array}{l}\text { Putative regulatory } \\
\text { mutation }\left(p c d^{1 j}\right)^{13}\end{array}$ & Mouse & Exacerbation by light ${ }^{14}$ & Unknown \\
\hline $\begin{array}{l}\text { Crumbs homologue } 1 \\
\text { (Crbl) }\end{array}$ & Knockout $^{15}$ & Mouse & Exacerbation by light $^{15}$ & LCA, RP12, RPCEV, ${ }^{16} \mathrm{PPCA}^{17}$ \\
\hline Mertk (Mertk) & Deletion $^{18}$ & Rat & $\begin{array}{l}\text { Protection by } \mathrm{DR}^{19-21} \\
\text { Exacerbation by light }^{21-23}\end{array}$ & $\mathrm{ARRP}^{24}$ \\
\hline Rds/peripherin (Rds) & Insertion $^{25}$ & Mouse & $\begin{array}{l}\text { No protection by } \mathrm{DR}^{26} \\
\text { Exacerbation by light }^{26}\end{array}$ & Several forms of retinal dystrophy ${ }^{27}$ \\
\hline Rhodopsin (RHO) & Thr4Arg $(T 4 R)^{28}$ & Dog & Exacerbation by light ${ }^{29}$ & $\mathrm{ADRP}^{30} 31$ \\
\hline Rhodopsin (Rho) & $\begin{array}{l}\text { Val20Gly, Pro23His, } \\
\text { Pro27Leu (VPP) }\end{array}$ & Mouse (tg) & $\begin{array}{l}\text { Protection by } \mathrm{DR}^{33} \\
\text { Exacerbation by light }^{34}\end{array}$ & $\mathrm{ADRP}^{35}$ \\
\hline Rhodopsin (Rho) & Pro23His $(\mathrm{P} 23 \mathrm{H})^{36} 37$ & Rat (tg) & $\begin{array}{l}\text { Protection by } \mathrm{DR}^{38} \\
\text { Exacerbation by light }^{38-42}\end{array}$ & $\mathrm{ADRP}^{35}$ \\
\hline $\begin{array}{l}\text { Rhodopsin kinase (Grkl, } \\
\text { Rhok) }\end{array}$ & Knockout $^{43}$ & Mouse & $\begin{array}{l}\text { Protection by } \mathrm{DR}^{43} \\
\text { Exacerbation by } \text { light }^{1043}\end{array}$ & Oguchi disease ${ }^{44}$ \\
\hline Rim protein (Abca4, Abcr) & Knockout $^{45}$ & Mouse & Prevention of $\mathrm{A} 2 \mathrm{E}$ accumulation by $\mathrm{DR}^{46}$ & $\begin{array}{l}\text { Stargardt disease and other retinal } \\
\text { dystrophies }{ }^{47}\end{array}$ \\
\hline RPE65 (Rpe65) & Knockout $^{48}$ & Mouse & $\begin{array}{l}\text { Protection by } \mathrm{DR}^{49} \\
\text { Resistance to light damage }\end{array}$ & $\begin{array}{l}\text { LCA, early onset severe retinal } \\
\text { dystrophy }\end{array}$ \\
\hline $\begin{array}{l}\text { Solute carrier family } 6, \\
\text { taurine transporter (Slc6ab, } \\
\text { Taut) }\end{array}$ & Knockout $^{52}$ & Mouse & Protection by $\mathrm{DR}^{53}$ & Unknown \\
\hline Tubby (Tub) & $\begin{array}{l}\text { Splice donor site } \\
\text { mutation }^{54} 55\end{array}$ & Mouse & Protection by $\mathrm{DR}^{56}$ & $\mathrm{ARRP}^{57}{ }^{58} \mathrm{LCA}^{59} \ddagger$ \\
\hline Unknown & Nervous mutation $(n r)^{60}$ & Mouse & $\begin{array}{l}\text { No protection by } \mathrm{DR}^{61} \\
\text { Exacerbation by light }^{14}\end{array}$ & Unknown \\
\hline $\begin{array}{l}\text { Not modified by light } \\
\text { Ceroid lipofuscinosis, } \\
\text { neuronal } 8(C \ln 8)\end{array}$ & Frameshiff $^{62}$ & Mouse & No protection by $\mathrm{DR}^{63}$ & $\mathrm{NCL}-8,{ }^{62}$ vLINCL ${ }^{64}$ \\
\hline $\begin{array}{l}\text { Microphthalmia associated } \\
\text { transcription factor (Mitf) }\end{array}$ & Asp222Asn (D222N) ${ }^{65}$ & Mouse & No protection by $\mathrm{DR}^{66}$ & $\begin{array}{l}\text { Waardenburg syndrome type } 11,{ }^{67} \text { Tietz } \\
\text { syndrome }^{68}\end{array}$ \\
\hline Rhodopsin (Rho) & Lys296Glu (K296E) ${ }^{69}$ & Mouse (tg) & No protection by $\mathrm{DR}^{69}$ & $\mathrm{ADRP}^{70}$ \\
\hline Rhodopsin (Rho) & Ser334ter ${ }^{71}$ & Rat $(\operatorname{tg})$ & $\begin{array}{l}\text { No protection by } \mathrm{DR}^{38} 72 \\
\text { No exacerbation by light in most } \\
\text { experiments }^{38} 4173\end{array}$ & ADRP§ \\
\hline Rhodopsin (Rho) & Knockout $^{74}$ & Mouse & Resistance to light damage ${ }^{50}$ & $\mathrm{ARRP}^{75}$ \\
\hline \multicolumn{5}{|c|}{$\begin{array}{l}\text { ADRP, autosomal dominant retinitis pigmentosa; ARRP, autosomal recessive retinitis pigmentosa; DR, dark rearing; LCA, Leber congenital amaurosis; NCL, } \\
\text { neuronal ceroid lipofuscinosis; PPCA, pigmented paravenous chorioretinal atrophy; RP12, retinitis pigmentosa type 12; RPCEV, retinitis pigmentosa with Coats- } \\
\text { like exudative vasculopathy; tg, transgenic; vLINCL, Turkish variant late infantile neuronal ceroid lipofuscinosis. } \\
\text { *"Protection" does not necessarily imply complete rescue. Light exposure protocols vary among studies, but "exacerbation by light" refers to accelerated } \\
\text { degeneration in light brighter than that used for routine animal housing in a given study. Because sufficiently bright light can cause retinal damage in wild type } \\
\text { animals, only cases in which exacerbation of degeneration significantly exceeds the damage produced in wild type controls by the same light regimen are } \\
\text { included. } \\
\text { †Except where noted, the listed human diseases arise from mutations in genes orthologous to those mutated in the respective animal models. Phenotypes may not } \\
\text { correspond precisely. Where more than one human disease is listed, these represent alternative phenotypes arising from mutations in the same gene. } \\
\ddagger \text { These phenotypes are associated with mutations in the human gene TULP1 (Tubby-like protein 1), which is related to mouse Tub, but not orthologous. } \\
\text { §Ser334ter transgenic rats exhibit dominant retinal degeneration, but this mutation has not been reported in human RP. }\end{array}$} \\
\hline
\end{tabular}

holds that since most light sources are located in the superior visual field, the inferior retina experiences greater exposure, accelerating the degeneration. $29798090-92$ Additional clinical evidence for this hypothesis has come from a case series describing two families with the $\mathrm{P} 23 \mathrm{H}$ mutation. ${ }^{80}$ In one family, a 28 year old man with an 8 year history of bright light exposure as a lifeguard and ski instructor had more advanced disease than his 52 year old mother. In the other family, one patient had atypical disease, with preferential loss of the inferior visual field and more advanced fundus changes in the superior retina. This patient had served in the navy, and had a history of bright light exposure in the inferior visual field from sunlight reflected from water and welding repairs to flooring.

Studies of three animal models of class Bl RP have demonstrated modification of degeneration by light. "VPP mice" carry a murine opsin transgene with the $\mathrm{P} 23 \mathrm{H}$ mutation, together with two other mutations (Val20Gly and Pro27Leu) not known to be pathogenic. Like class Bl patients, they exhibit dominantly inherited retinal degneration, ${ }^{32}$ more rapid photoreceptor loss in the inferior retina when housed with overhead lighting, ${ }^{33}$ and delayed dark adaptation..$^{93}$ Rearing VPP mice in the dark slows, but does not completely prevent, the degeneration. Dark rearing also eliminates the difference between superior and inferior retina, supporting the conclusion that this difference is due to greater light exposure in the inferior retina. ${ }^{33}$ A 24 hour exposure to bright light that has no effect on wild type littermates accelerates the degeneration in VPP mice. ${ }^{34}$

Analysis of rats carrying a murine opsin transgene with the $\mathrm{P} 23 \mathrm{H}$ mutation has yielded results similar to those from the VPP mice. Dark rearing slows the rate of degeneration in $\mathrm{P} 23 \mathrm{H}$ rats, ${ }^{38}$ while exposure to bright light accelerates it. ${ }^{38-41}$ Degeneration is slower in very dim light compared to moderate room light. ${ }^{42}$

The third animal model offers a particularly dramatic example of the effects of light. A naturally occurring dominant retinal degeneration in English Mastiff dogs is caused by a RHO mutation that changes threonine to arginine in the fourth codon (Thr4Arg, T4R) ${ }^{28}$ This mutant is likely to have properties similar to Thr4Lys (replacing threonine with lysine, which like arginine is positively charged at 
physiological pH), a mutation identified in human ADRP with regional degeneration. ${ }^{30} 31$ The $\mathrm{T} 4 \mathrm{R}$ dog resembles human class Bl RP in having delayed dark adaptation after bright flashes, and regional photoreceptor loss. ${ }^{28}$ Cideciyan and colleagues used this large animal model to ask whether light exposure at levels routinely encountered in ophthalmological clinical settings could accelerate the course of disease. ${ }^{29}$ They found that standard fundus photography in young dogs, before the usual onset of photoreceptor loss in this model, caused rapid and severe degeneration restricted to the photographed areas, with a sharp boundary separating damaged from normal appearing retina. Similar results were obtained with prolonged focal light exposures comparable to indirect ophthalmoscopy, but not with a standard ERG protocol that delivered a much lower light dose. ${ }^{29}$

The mechanisms of photoreceptor death arising from $\mathrm{RHO}$ mutations associated with the class $\mathrm{Bl}$ phenotype are incompletely understood. When expressed in heterologous cells in culture, the mutant opsins are prone to misfolding and aggregation, regenerate poorly with 11 -cis-retinal, and are inefficiently transported to the plasma membrane, unlike the wild type protein. ${ }^{94-98} \mathrm{P} 23 \mathrm{H}$ is targeted for degradation by the ubiquitin proteasome system, but also impairs this critical pathway, and may interfere with the processing of normal opsin. ${ }^{97} 98$ Photoreceptors may be poorly suited to degrade large amounts of misfolded, mislocalised, or aggregated opsin, because under normal circumstances, most opsin is shed with the outer segment discs and degraded by the retinal pigment epithelium (RPE). ${ }^{78}$ Protein misfolding and aggregation have been implicated in the pathogenesis of several neurodegenerative diseases. ${ }^{99}$

Light could accelerate degeneration through non-specific toxicity to photoreceptors already stressed by the effects of a mutation, or through a specific interaction with mutant rhodopsin. Experiments with cultured photoreceptors have suggested that activation of mislocalised rhodopsin could kill rods by stimulating inappropriate signalling pathways. ${ }^{100}$ Mislocalisation has been detected in mice carrying a human $\mathrm{P} 23 \mathrm{H}$ opsin transgene ${ }^{101}{ }^{102}$ and possibly in VPP mice, ${ }^{103}$ but not in $\mathrm{P} 23 \mathrm{H}$ rats $^{72}$ or T4R dogs. ${ }^{28}$ Postmortem analysis of the retina from a patient with the class $\mathrm{Bl}$ associated mutation, Thrl7Met, did not demonstrate rhodopsin mislocalisation in rods that had not degenerated at the time of death. ${ }^{90}$

Alternatively, mutant rhodopsin may cause abnormalities of phototransduction. ERG analyses of VPP mice and P23H patients have suggested that the lifetime of activated rhodopsin is prolonged, although it could not be determined whether this species represented mutant rhodopsin, the normal protein, or both. ${ }^{104}{ }^{105}$ Photoexcited rhodopsin triggers the phototransduction cascade by activating transducin. When VPP mice are crossed with knockout mice lacking functional transducin, introducing a genetic block of the cascade, their degeneration in standard cyclic lighting is slowed, supporting a role for phototransduction. ${ }^{106}$ A third hypothesis proposes that misfolded opsin destabilises outer segment discs, leading to excessive shedding in response to light, which may contribute to photoreceptor stress and eventual death. ${ }^{107}$ Full recovery of rod sensitivity would depend on the slow process of new disc formation, which could explain the greatly prolonged late phase of dark adaptation observed in patients with class Bl RP. ${ }^{88}$ Massive shedding of outer segment tips was observed after retinal photography in T4R dogs, consistent with this hypothesis. ${ }^{29}$

Whatever the mechanism by which light accelerates degeneration may be, these studies point to two general conclusions. Firstly, until more is known about the effects of light on RP patients with specific mutations, it would be prudent to minimise light exposure during office examinations, fundus photography, and ocular surgery for patients with the class Bl phenotype. ${ }^{29}$ The use of hats and sunglasses during regular exposure to bright sunlight may also be advisable. Secondly, this would be a logical population in which to conduct further trials of light restriction. ${ }^{29}$

\section{OGUCHI DISEASE AND RETINAL DEGENERATION: IMPAIRED RHODOPSIN DEACTIVATION}

Following excitation by light, rhodopsin must be rapidly deactivated to restore the rod's full sensitivity. Two proteins are crucial for this process. Rhodopsin kinase (RK) phosphorylates photoactivated rhodopsin at serine and threonine residues near the carboxyl terminus. ${ }^{108} 109$ Arrestin binds to phosphorylated rhodopsin and prevents further activation of transducin. ${ }^{110}$

Mutations in either RK or arrestin cause Oguchi disease, an autosomal recessive disorder characterised by prolonged insensitivity of rod vision following light exposure. ${ }^{114} 4111112$ In the absence of the normal quenching pathway, photoexcited rhodopsin continues to activate transducin until deactivated by a much slower process, possibly regeneration with 11-cis-retinal. This persistent activity desensitises the rod, markedly slowing dark adaptation. ${ }^{44113114}$ The fundus displays a golden discoloration that disappears with dark adaptation, called the Mizuo-Nakamura phenomenon. Although Oguchi disease is usually described as a form of stationary night blindness, patients with the most common arrestin mutation (1147delA) may also have degenerative features characteristic of RP. ${ }^{12}{ }^{114-117}$ Phenotypically distinct Oguchi disease and RP may be found in different members of the same family with this mutation, ${ }^{117}$ or a single patient may have features of both diseases. ${ }^{12} 115116$ The same mutation has been identified in patients with autosomal recessive RP who had no relatives diagnosed with Oguchi disease. ${ }^{12}$ A different arrestin mutation (Arg 193ter) has similarly been identified in two siblings with Oguchi disease, one of whom had signs of degeneration while the other did not. ${ }^{118}$ Therefore, each of these arrestin mutations can produce a spectrum of disease, presumably under the influence of modifying environmental or genetic factors. It remains to be determined whether RK mutations can cause retinal degeneration. ${ }^{19}$

Rods from knockout mice lacking either RK or arrestin exhibit prolonged photoresponses, consistent with the pathophysiology of Oguchi disease. ${ }^{843}$ Photoresponses in RK knockout rods also have greater than normal amplitudes. ${ }^{43}$ Both strains of knockout mice undergo light dependent photoreceptor degeneration. Under dim cyclic lighting, the only histological abnormality reported in the RK mutant is shortening of rod outer segments. Exposure to brighter light for 24 hours, which does not damage the wild type retina, causes degeneration in RK mutants. ${ }^{43}$ Similarly, arrestin knockout mice exhibit gradual degeneration in cyclic light, which is greatly accelerated by a constant light regimen that causes no damage in wild type mice. ${ }^{9}$ Mice of both genotypes have normal retinal morphology when dark reared. ${ }^{93}$ The prolonged photoresponses of RK and arrestin knockout mice, and the strongly light dependent nature of their degeneration, suggest that excessive activation of the phototransduction cascade causes photoreceptor death in these mutants. ${ }^{93} 120$ This conclusion is supported by analysis of double knockout mice lacking RK and transducin, or arrestin and transducin. The transducin mutation largely prevents the degeneration induced by light in the RK and arrestin single knockouts. ${ }^{10}$

The animal results suggest that light exposure could be an important modifier of the Oguchi disease phenotype, at least in patients with arrestin mutations. Phototransduction activity is excessive in all patients, but may remain tolerable to photoreceptors in those with moderate light exposure. Those exposed to brighter light over time may be at risk of 
degeneration. There is as yet no direct evidence for this hypothesis in patients, but it is consistent with a body of evidence suggesting that constitutive phototransduction can cause either night blindness or retinal degeneration, possibly depending on the degree of transducin activation. ${ }^{121}{ }^{122}$ For example, three rhodopsin mutations (Gly90Asp, Thr94Ile, and Ala292Glu) cause autosomal dominant congenital night blindness with no reported evidence of degeneration, ${ }^{123}{ }^{124}$ or with degeneration occurring only later in life. ${ }^{125}$ Biochemical experiments, ${ }^{123}{ }^{126-128}$ transgenic animal models, ${ }^{121}{ }^{129}$ and studies of patients ${ }^{125}$ have shown that the mutant opsins activate transducin at low levels even in darkness and desensitise rods, as though they were exposed to a weak background light. In contrast, studies of knockout mice lacking RPE65 suggest that higher levels of constitutive phototransduction can cause degeneration. Loss of RPE65 function disrupts production of 11-cis-retinal. ${ }^{48} 130131$ Therefore, opsin lacks the chromophore and is thought to activate transducin aberrantly, causing rods to behave as if strongly light adapted ${ }^{49}{ }^{132-34}$ (although this has been disputed). ${ }^{135} 136$ Photoreceptor degeneration in this model is rescued by a transducin null mutation, implicating constitutive phototransduction as its cause. ${ }^{134}$ Human RPE65 mutations cause severe, early onset retinal dystrophy phenotypes including Leber congenital amaurosis. ${ }^{51}$ Light exposure presumably affects the level of abnormal phototransduction in patients with arrestin mutations, and might determine whether their disease manifests as night blindness or degeneration.

Of course, other environmental or genetic factors 550106137 might also modulate phototransduction activity, or the vulnerability of photoreceptors, in these patients. However, a report of a patient with Oguchi disease and degeneration preferentially involving the inferior retina, ${ }^{116}$ similar to the class Bl phenotype of ADRP, hints at a possible role for light. As discussed earlier, this regional predilection could result from increased light exposure in the superior visual field.

\section{STARGARDT DISEASE: TOXIC BYPRODUCTS OF VISION}

Stargardt disease (STGD) is a hereditary macular dystrophy whose features often include progressive loss of central vision with onset during the first or second decade of life, macular atrophy, fundus flecks, and a dark choroid on fluorescein angiography. ${ }^{138} 139$ Histopathological changes are most pronounced in and near the macula. These include RPE degeneration and massive accumulation in RPE cells of lipofuscin, believed to consist mainly of non-degradable material derived from ingested photoreceptor outer segments. ${ }^{140-142}$ These findings, together with detailed analysis of fundus and psychophysical abnormalities in patients, ${ }^{143}$ have supported the hypothesis that degeneration of photoreceptors in STGD is secondary to RPE dysfunction and loss. The disease shows autosomal recessive inheritance and is caused by mutations in $A B C A 4$ (also known as $A B C R$ ). ${ }^{144}$ This gene encodes rim protein $(\mathrm{RmP}),{ }^{145}$ a transporter localised to the rims of photoreceptor outer segment discs. ${ }^{146-148} A B C A 4$ mutations have also been identified in fundus flavimaculatus (a variant of STGD), ${ }^{149}$ autosomal recessive $\mathrm{RP},{ }^{150}{ }^{151}$ and cone-rod dystrophy. ${ }^{151}$ A proposed link to age related macular degeneration ${ }^{152}{ }^{153}$ is less certain. ${ }^{154-156}$ The clinical phenotype may depend on the degree of residual RmP activity. ${ }^{157}$

Insights into the pathogenesis of STGD and its relation to light have come from analysis of knockout mice lacking a functional Abcr gene, which exhibit abnormalities of the visual cycle. ${ }^{45}$ During recovery from a photoresponse, activated rhodopsin decays to release all-trans-retinal inside the outer segment disc. All-trans-retinal reacts with a phospholipid component of the disc membrane to form
$N$-retinylidene-phosphatidylethanolamine ( $N$-ret-PE). RmP translocates $N$-ret-PE from the intradiscal to the outer (cytoplasmic) leaflet of the disc membrane, allowing alltrans-retinal to be released, reduced, transported to the RPE, and converted back to 11-cis-retinal. ${ }^{45}{ }^{158}$ In the absence of functional RmP, $N$-ret-PE remains trapped inside the disc, forming further intermediates. When the disc is phagocytosed by the RPE, a final set of reactions converts these to $\mathrm{N}$ retinylidene- $N$-retinylethanolamine (A2E), ${ }^{46}$ a component of lipofuscin with several potentially toxic effects on RPE cells. ${ }^{159-165}$ A2E is dramatically elevated in the RPE in both Abcr knockout mice ${ }^{45}$ and STGD patients. ${ }^{46}$ The greater lipofuscin accumulation and RPE degeneration in the macula in STGD may be a consequence of the macula's high ratio of photoreceptors to RPE cells. ${ }^{45}$

In this model, $\mathrm{A} 2 \mathrm{E}$ is a toxic byproduct of the visual cycle that accumulates to abnormal levels in the RPE of $\mathrm{Abcr}$ mutant mice and STGD patients as a consequence of rhodopsin activation and retention of $N$-ret-PE within outer segment discs. Therefore, A2E formation should be suppressed by preventing rhodopsin activation. Dark rearing the knockout mice prevents accumulation of A2E, suggesting that light deprivation might slow the progression of STGD and other dystrophies caused by $A B C A 4$ mutations. ${ }^{46}$

Further studies have suggested an alternative strategy for limiting $\mathrm{A} 2 \mathrm{E}$ formation. These began with the observation that some patients taking isotretinoin, a retinoid prescribed for the treatment of severe acne, experience disturbances of night vision. ${ }^{166}$ Isotretinoin inhibits the production of 11 -cisretinal, interfering with rhodopsin regeneration. ${ }^{167}{ }^{168}$ Chronic isotretinoin treatment suppresses A2E formation and lipofuscin accumulation in the RPE of $A b c r$ mutant mice, presumably by reducing the availability of all-trans-retinal to form $N$-ret-PE in photoreceptor outer segments. ${ }^{169}$ It remains to be determined whether this or alternative pharmacological approaches ${ }^{170-172}$ can safely and effectively treat patients with STGD or other diseases associated with lipofuscin accumulation.

\section{CONCLUSIONS}

Our understanding of the role of light in retinal degeneration continues to evolve through the use of clinical, animal, and in vitro approaches. A growing body of evidence strongly suggests that light exposure can modify the course of at least some retinal dystrophies. This applies particularly to autosomal dominant RP with the class Bl (regional) phenotype, for which marked acceleration by fundus photography has been demonstrated in a large animal model. ${ }^{29}$ However, carefully designed trials in patients of known genotype are required to confirm hypotheses generated by studies of animal models. Until such results become available, and in the many cases for which the underlying mutations remain unknown, it may be prudent to avoid unnecessary exposure to bright light, especially in clinical settings.

\section{ACKNOWLEDGEMENTS}

Supported by the Foundation Fighting Blindness, That Man May See, Inc, the Bernard A Newcomb Macular Degeneration Fund, a Career Development Award from Research to Prevent Blindness (JLD), and by NIH grants EY00415, EY01919, and EY02162.

\footnotetext{
Authors' affiliations

D M Paskowitz, Medical Scientist Training Program and Beckman Vision Center, UCSF School of Medicine, San Francisco, CA, USA

M M LaVail, J L Duncan, Beckman Vision Center, UCSF School of Medicine, San Francisco, CA, USA

Competing interests: none.
} 


\section{REFERENCES}

1 Berson EL. Light deprivation for early retinitis pigmentosa. A hypothesis. Arch Ophthalmol 1971;85:521-9.

2 Berson EL. Light deprivation and retinitis pigmentosa. Vis Res 1980;20:1179-84.

3 Miyake $Y$, Sugita $S$, Horiguchi $M$, et al. Light deprivation and retinitis pigmentosa. Am J Ophthalmol 1990;1 10:305-6.

4 Stone J, Maslim J, Valter-Kocsi K, et al. Mechanisms of photoreceptor death and survival in mammalian retina. Prog Retin Eye Res 1999;18:689-735.

5 Wenzel A, Grimm C, Samardzija M, et al. Molecular mechanisms of lightinduced photoreceptor apoptosis and neuroprotection for retinal degeneration. Prog Retin Eye Res 2005;24:275-306.

6 Reme CE. The dark side of light: rhodopsin and the silent death of vision. The Proctor Lecture. Invest Ophthalmol Vis Sci 2005;46:2671-82.

7 Kiselev A, Socolich M, Vinos J, et al. A molecular pathway for lightdependent photoreceptor apoptosis in Drosophila. Neuron 2000;28:139-52

$8 \mathrm{Xu}$ J, Dodd RL, Makino CL, et al. Prolonged photoresponses in transgenic mouse rods lacking arrestin. Nature 1997;389:505-9.

9 Chen J, Simon MI, Matthes MT, et al. Increased susceptibility to light damage in an arrestin knockout mouse model of Oguchi disease (stationary night blindness). Invest Ophthalmol Vis Sci 1999;40:2978-82.

10 Hao W, Wenzel A, Obin MS, et al. Evidence for two apoptotic pathways in light-induced retinal degeneration. Nat Genet 2002;32:254-60.

11 Fuchs S, Nakazawa M, Maw M, et al. A homozygous 1-base pair deletion in the arrestin gene is a frequent cause of Oguchi disease in Japanese. Nat Genet 1995; 10:360-2.

12 Nakazawa M, Wada Y, Tamai M. Arrestin gene mutations in autosomal recessive retinitis pigmentosa. Arch Ophthalmol 1998;1 16:498-501.

13 Fernandez-Gonzalez A, La Spada AR, Treadaway J, et al. Purkinje cell degeneration ( $\mathrm{pcd}$ ) phenotypes caused by mutations in the axotomy-induced gene, Nnal. Science 2002;295:1904-6.

14 LaVail MM, Gorrin GM, Yasumura D, et al. Increased susceptibility to constant light in $\mathrm{nr}$ and pcd mice with inherited retinal degenerations. Invest Ophthalmol Vis Sci 1999;40:1020-4.

15 Van de Pavert SA, Kantardzhieva A, Malysheva A, et al. Crumbs homologue 1 is required for maintenance of photoreceptor cell polarization and adhesion during light exposure. J Cell Sci 2004;117:4169-77.

16 den Hollander Al, Davis J, van der Velde-Visser SD, et al. CRB1 mutation spectrum in inherited retinal dystrophies. Hum Mutat 2004;24:355-69.

17 McKay GJ, Clarke S, Davis JA, et al. Pigmented paravenous chorioretinal atrophy is associated with a mutation within the crumbs homolog 1 (CRB1) gene. Invest Ophthalmol Vis Sci 2005;46:322-8.

18 D'Cruz PM, Yasumura D, Weir J, et al. Mutation of the receptor tyrosine kinase gene Mertk in the retinal dystrophic RCS rat. Hum Mol Genet 2000;9:645-51.

19 Dowling JE, Sidman RL. Inherited retinal dystrophy in the rat. J Cell Biol 1962;14:73-109.

20 LaVail MM, Battelle BA. Influence of eye pigmentation and light deprivation on inherited retinal dystrophy in the rat. Exp Eye Res 1975;21:167-92.

21 Kaitz M, Auerbach E. Retinal degeneration in RCS rats raised under ambient light levels. Vision Res 1979;19:79-81.

22 Noell WK. Some animal models of retinitis pigmentosa. Adv Exp Med Biol 1977;77:87-91

23 Organisciak DT, Li M, Darrow RM, et al. Photoreceptor cell damage by light in young Royal College of Surgeons rats. Curr Eye Res 1999;19:188-96.

24 Gal A, Li Y, Thompson DA, et al. Mutations in MERTK, the human orthologue of the RCS rat retinal dystrophy gene, cause retinitis pigmentosa. Nat Genet 2000;26:270-1.

$25 \mathrm{Ma} \mathrm{J}$, Norton JC, Allen AC, et al. Retinal degeneration slow (rds) in mouse results from simple insertion of a thaplotype-specific element into proteincoding exon II. Genomics 1995;28:212-9.

26 Sanyal S, Hawkins RK. Development and degeneration of retina in rds mutant mice: effects of light on the rate of degeneration in albino and pigmented homozygous and heterozygous mutant and normal mice. Vis Res 1986;26:1177-85.

27 OMIM 179605, http://www.ncbi.nlm.nih.gov/Omim

28 Kijas JW, Cideciyan AV, Aleman TS, et al. Naturally occurring rhodopsin mutation in the dog causes retinal dysfunction and degeneration mimicking human dominant retinitis pigmentosa. Proc Natl Acad Sci USA 2002; 99:6328-33.

29 Cideciyan AV, Jacobson SG, Aleman TS, et al. In vivo dynamics of retinal injury and repair in the rhodopsin mutant dog model of human retinitis pigmentosa. Proc Natl Acad Sci USA 2005;102:5233-8.

30 Bunge S, Wedemann H, David D, et al. Molecular analysis and genetic mapping of the rhodopsin gene in families with autosomal dominant retinitis pigmentosa. Genomics 1993:17:230-3.

31 Van den Born LI, van Schooneveld MJ, de Jong LA, et al. Thr4Lys rhodopsin mutation is associated with autosomal dominant retinitis pigmentosa of the cone-rod type in a small Dutch family. Ophthalmic Genet 1994;15:51-60.

32 Naash MI, Hollyfield JG, al-Ubaidi MR, et al. Simulation of human autosomal dominant retinitis pigmentosa in transgenic mice expressing a mutated murine opsin gene. Proc Natl Acad Sci USA 1993;90:5499-503.

33 Naash ML, Peachey NS, Li ZY, et al. Light-induced acceleration of photoreceptor degeneration in transgenic mice expressing mutant rhodopsin. Invest Ophthalmol Vis Sci 1996;37:775-82.

34 Wang $M$, Lam TT, Tso MO, et al. Expression of a mutant opsin gene increases the susceptibility of the retina to light damage. Vis Neurosci $1997 ; 14: 55-62$
35 Dryja TP, McGee TL, Reichel E, et al. A point mutation of the rhodopsin gene in one form of retinitis pigmentosa. Nature 1990;343:364-6.

36 Lewin AS, Drenser KA, Hauswirth WW, et al. Ribozyme rescue of photoreceptor cells in a transgenic rat model of autosomal dominant retinitis pigmentosa. Nat Med 1998;4:967-71.

37 Machida S, Kondo M, Jamison JA, et al. P23H rhodopsin transgenic rat: correlation of retinal function with histopathology. Invest Ophthalmol Vis Sci 2000:41:3200-9.

38 Organisciak DT, Darrow RM, Barsalou L, et al. Susceptibility to retinal light damage in transgenic rats with rhodopsin mutations. Invest Ophthalmol Vis Sci 2003;44:486-92.

39 Nir I, Harrison JM, Liu C, et al. Extended photoreceptor viability by light stress in the RCS rats but not in the opsin $\mathrm{P} 23 \mathrm{H}$ mutant rats. Invest Ophthalmol Vis Sci 2001;42:842-9.

40 Bicknell IR, Darrow R, Barsalou L, et al. Alterations in retinal rod outer segment fatty acids and light-damage susceptibility in $\mathrm{P} 23 \mathrm{H}$ rats. Mol Vis 2002:8:333-40

41 Vaughan DK, Coulibaly SF, Darrow RM, et al. A morphometric study of lightinduced damage in transgenic rat models of retinitis pigmentosa. Invest Ophthalmol Vis Sci 2003;44:848-55

42 Walsh N, van Driel D, Lee D, et al. Multiple vulnerability of photoreceptors to mesopic ambient light in the $\mathrm{P} 23 \mathrm{H}$ transgenic rat. Brain Res 2004; 1013:194-203.

43 Chen CK, Burns ME, Spencer M, et al. Abnormal photoresponses and lightinduced apoptosis in rods lacking rhodopsin kinase. Proc Natl Acad Sci USA 1999:96:3718-22.

44 Yamamoto S, Sippel KC, Berson EL, et al. Defects in the rhodopsin kinase gene in the Oguchi form of stationary night blindness. Nat Genet 1997; 15:175-8

45 Weng J, Mata NL, Azarian SM, et al. Insights into the function of Rim protein in photoreceptors and etiology of Stargardt's disease from the phenotype in abcr knockout mice. Cell 1999;98:13-23.

46 Mata NL, Weng J, Travis GH. Biosynthesis of a major lipofuscin fluorophore in mice and humans with $A B C R$-mediated retinal and macular degeneration. Proc Natl Acad Sci USA 2000;97:7154-9.

47 OMIM 601691, http://www.ncbi.nlm.nih.gov/Omim

48 Redmond TM, Yu S, Lee E, et al. Rpe65 is necessary for production of 11 -cisvitamin A in the retinal visual cycle. Nat Genet 1998;20:344-51.

49 Fan J, Woodruff ML, Cilluffo MC, et al. Opsin activation of transduction in the rods of dark-reared Rpe65 knockout mice. J Physiol 2005;568:83-95.

50 Grimm C, Wenzel A, Hafezi F, et al. Protection of Rpe65-deficient mice identifies rhodopsin as a mediator of light-induced retinal degeneration. Nat Genet 2000;25:63-6.

51 Thompson DA, Gal A. Vitamin A metabolism in the retinal pigment epithelium: genes, mutations, and diseases. Prog Retin Eye Res 2003;22:683-703.

52 Heller-Stilb B, van Roeyen C, Rascher K, et al. Disruption of the taurine transporter gene (taut) leads to retinal degeneration in mice. FASEB 2002; 16:231-3

53 Rascher K, Servos G, Berthold G, et al. Light deprivation slows but does not prevent the loss of photoreceptors in taurine transporter knockout mice. Vis Res 2004:44:2091-100.

54 Noben-Trauth K, Naggert JK, North MA, et al. A candidate gene for the mouse mutation tubby. Nature 1996;380:534-8

55 Kleyn PW, Fan W, Kovats SG, et al. Identification and characterization of the mouse obesity gene tubby: a member of a novel gene family. Cell 1996;85:281-90

56 Kong L, Li F, Soleman CE, et al. Bright cyclic light accelerates photoreceptor cell degeneration in tubby mice. Neurobiol Dis 2005; (in press).

57 Hagstrom SA, North MA, Nishina PL, et al. Recessive mutations in the gene encoding the tubby-like protein TULP1 in patients with retinitis pigmentosa. Nat Genet 1998; 18:174-6.

58 Banerjee P, Kleyn PW, Knowles JA, et al. TULP1 mutation in two extended Dominican kindreds with autosomal recessive retinitis pigmentosa. Nat Genet 1998; 18:177-9.

59 Hanein S, Perrault I, Gerber S, et al. Leber congenital amaurosis: comprehensive survey of the genetic heterogeneity, refinement of the clinical definition, and genotype-phenotype correlations as a strategy for molecular diagnosis. Hum Mutat 2004;23:306-17.

60 Mullen RJ, LaVail MM. Two types of retinal degeneration in cerebellar mutant mice. Nature 1975;258:528-30.

61 LaVail MM. Interaction of environmental light and eye pigmentation with inherited retinal degenerations. Vis Res 1980;20:1173-7.

62 Ranta S, Zhang Y, Ross B, et al. The neuronal ceroid lipofuscinoses in human EPMR and mnd mutant mice are associated with mutations in CLN8. Nat Genet 1999;23:233-6

63 Messer A, Plummer J, MacMillen MC, et al. Genetics of primary and timing effects in the mnd mouse. Am J Med Genet 1995;57:361-4.

64 Ranta S, Topcu M, Tegelberg S, et al. Variant late infantile neuronal ceroid lipofuscinosis in a subset of Turkish patients is allelic to Northern epilepsy. Hum Mutat 2004;23:300-5.

65 Steingrimsson E, Moore KJ, Lamoreux ML, et al. Molecular basis of mouse microphthalmia (mi) mutations helps explain their developmental and phenotypic consequences. Nat Genet 1994;8:256-63.

66 Smith SB, Cope BK, McCoy JR. Effects of dark-rearing on the retinal degeneration of the C57BL/6-mivit/mivit mouse. Exp Eye Res 1994; $58: 77-84$

67 Tassabehii M, Newton VE, Read AP. Waardenburg syndrome type 2 caused by mutations in the human microphthalmia (MITF) gene. Nat Genet 1994;8:251-5 
68 Smith SD, Kelley PM, Kenyon JB, et al. Tietz syndrome (hypopigmentation/ deafness) caused by mutation of MITF. J Med Genet 2000;37:446-8.

69 Li T, Franson WK, Gordon JW, et al. Constitutive activation of phototransduction by K296E opsin is not a cause of photoreceptor degeneration. Proc Natl Acad Sci USA 1995;92:3551-5.

70 Keen TJ, Inglehearn CF, Lester DH, et al. Autosomal dominant retinitis pigmentosa: four new mutations in rhodopsin, one of them in the retinal attachment site. Genomics 1991;11:199-205.

71 Liu C, Li Y, Peng M, et al. Activation of caspase-3 in the retina of transgenic rats with the rhodopsin mutation S334ter during photoreceptor degeneration. J Neurosci 1999;19:4778-85.

72 Green ES, Menz MD, LaVail MM, et al. Characterization of rhodopsin missorting and constitutive activation in a transgenic rat model of retinitis pigmentosa. Invest Ophthalmol Vis Sci 2000;41:1546-53.

73 Ranchon I, LaVail MM, Kotake Y, et al. Free radical trap phenyl-N-tertbutylnitrone protects against light damage but does not rescue P23H and S334ter rhodopsin transgenic rats from inherited retinal degeneration. J Neurosci 2003:23:6050-7.

74 Humphries MM, Rancourt D, Farrar GJ, et al. Retinopathy induced in mice by targeted disruption of the rhodopsin gene. Nat Genet 1997;15:216-19.

75 Rosenfeld PJ, Cowley GS, McGee TL, et al. A null mutation in the rhodopsin gene causes rod photoreceptor dysfunction and autosomal recessive retinitis pigmentosa. Nat Genet 1992;1:209-13.

76 Sung $\mathrm{CH}$, Davenport CM, Hennessey JC, et al. Rhodopsin mutations in autosomal dominant retinitis pigmentosa. Proc Natl Acad Sci USA 1991;88:6481-5

77 Dryja TP, McEvoy JA, McGee TL, et al. Novel rhodopsin mutations Gly 14 Val and Gln184Pro in dominant retinitis pigmentosa. Invest Ophthalmol Vis Sci 2000;41:3124-7.

78 Dryja TP, Hahn LB, Cowley GS, et al. Mutation spectrum of the rhodopsin gene among patients with autosomal dominant retinitis pigmentosa. Proc Natl Acad Sci USA 1991;88:9370-4.

79 Cideciyan AV, Hood DC, Huang Y, et al. Disease sequence from mutant rhodopsin allele to rod and cone photoreceptor degeneration in man. Proc Natl Acad Sci USA 1998;95:7103-8.

80 Heckenlively JR, Rodriguez JA, Daiger SP. Autosomal dominant sectoral retinitis pigmentosa. Two families with transversion mutation in codon 23 of rhodopsin. Arch Ophthalmol 1991;109:84-91.

81 Berson EL, Rosner B, Sandberg MA, et al. Ocular findings in patients with autosomal dominant retinitis pigmentosa and a rhodopsin gene defect (Pro23-His). Arch Ophthalmol 1991:109:92-101.

82 Jacobson SG, Kemp CM, Sung CH, et al. Retinal function and rhodopsin levels in autosomal dominant retinitis pigmentosa with rhodopsin mutations. Am J Ophthalmol 1991;112:256-71.

83 Fishman GA, Stone EM, Gilbert LD, et al. Ocular findings associated with a rhodopsin gene codon 58 transversion mutation in autosomal dominant retinitis pigmentosa. Arch Ophthalmol 1991;109:1387-93.

84 Stone EM, Kimura AE, Nichols BE, et al. Regional distribution of retinal degeneration in patients with the proline to histidine mutation in codon 23 of the rhodopsin gene. Ophthalmology 1991:98:1806-13.

85 Fishman GA, Stone EM, Sheffield VC, et al. Ocular findings associated with rhodopsin gene codon 17 and codon 182 transition mutations in dominant retinitis pigmentosa. Arch Ophthalmol 1992;110:54-62

86 Kemp CM, Jacobson SG, Roman AJ, et al. Abnormal rod dark adaptation in autosomal dominant retinitis pigmentosa with proline-23-histidine rhodopsin mutation. Am J Ophthalmol 1992;113:165-74.

87 Fishman GA, Stone EM, Gilbert LD, et al. Ocular findings associated with a rhodopsin gene codon 106 mutation. Glycine-to-arginine change in autosomal dominant retinitis pigmentosa. Arch Ophthalmol $1992 ; 110: 646-53$.

88 Moore AT, Fitzke FW, Kemp CM, et al. Abnormal dark adaptation kinetics in autosomal dominant sector retinitis pigmentosa due to rod opsin mutation. Br J Ophthalmol 1992;76:465-9.

89 Hayakawa M, Hotta Y, Imai $Y$, et al. Clinical features of autosomal dominant retinitis pigmentosa with rhodopsin gene codon 17 mutation and retinal neovascularization in a Japanese patient. Am J Ophthalmol 1993; 115:168-73

90 Li ZY, Jacobson SG, Milam AH. Autosomal dominant retinitis pigmentosa caused by the threonine-17-methionine rhodopsin mutation: retinal histopathology and immunocytochemistry. Exp Eye Res 1994;58:397-408.

91 Adrian W, Everson RW, Schmidt I. Protection against photic damage in retinitis pigmentosa. Adv Exp Med Biol 1977;77:233-47.

92 Schwartz L, Boelle PY, D'Hermies F, et al. Blue light dose distribution and retinitis pigmentosa visual field defects: an hypothesis. Med Hypotheses 2003;60:644-9

93 Goto $Y$, Peachey NS, Ripps $H$, et al. Functional abnormalities in transgenic mice expressing a mutant rhodopsin gene. Invest Ophthalmol Vis Sci 1995;36:62-71

94 Sung CH, Schneider BG, Agarwal N, et al. Functional heterogeneity of mutant rhodopsins responsible for autosomal dominant retinitis pigmentosa. Proc Natl Acad Sci USA 1991;88:8840-4

95 Kaushal S, Khorana HG. Structure and function in rhodopsin. 7. Point mutations associated with autosomal dominant retinitis pigmentosa. Biochemistry 1994;33:6121-8.

96 Liu X, Garriga P, Khorana HG. Structure and function in rhodopsin: correct folding and misfolding in two point mutants in the intradiscal domain of rhodopsin identified in retinitis pigmentosa. Proc Natl Acad Sci USA 1996:93:4554-9.

97 Saliba RS, Munro PM, Luthert PJ, et al. The cellular fate of mutant rhodopsin: quality control, degradation and aggresome formation. J Cell Sci 2002;115:2907-18.
98 Illing ME, Rajan RS, Bence NF, et al. A rhodopsin mutant linked to autosomal dominant retinitis pigmentosa is prone to aggregate and interacts with the ubiquitin proteasome system. J Biol Chem 2002;277:34150-60.

99 Ross CA, Poirier MA. Protein aggregation and neurodegenerative disease. Nat Med 2004; 10(Suppl):S10-7.

100 Alfinito PD, Townes-Anderson E. Activation of mislocalized opsin kills rod cells: a novel mechanism for rod cell death in retinal disease. Proc Natl Acad Sci USA 2002;99:5655-60.

101 Olsson JE, Gordon JW, Pawlyk BS, et al. Transgenic mice with a rhodopsin mutation (Pro23His): a mouse model of autosomal dominant retinitis pigmentosa. Neuron 1992;9:815-30.

102 Roof DJ, Adamian M, Hayes A. Rhodopsin accumulation at abnormal sites in retinas of mice with a human $\mathrm{P} 23 \mathrm{H}$ rhodopsin transgene. Invest Ophthalmol Vis Sci 1994;35:4049-62.

103 Wu TH, Ting TD, Okajima TI, et al. Opsin localization and rhodopsin photochemistry in a transgenic mouse model of retinitis pigmentosa. Neuroscience 1998;87:709-17.

104 Birch DG, Hood DC, Nusinowitz S, et al. Abnormal activation and inactivation mechanisms of rod transduction in patients with autosomal dominant retinitis pigmentosa and the pro-23-his mutation. Invest Ophthalmol Vis Sci 1995:36:1603-14.

105 Goto Y, Peachey NS, Ziroli NE, et al. Rod phototransduction in transgenic mice expressing a mutant opsin gene. J Opt Soc Am A Opt Image Sci Vis 1996; 13:577-85.

106 Samardzija M, Wenzel A, Naash M, et al. Rpe65 as a modifier gene for inherited retinal degeneration. Eur J Neurosci 2006;23:1028-34.

107 Berson EL. Retinitis pigmentosa: unfolding its mystery. Proc Natl Acad Sci USA 1996;93:4526-8.

108 Mendez A, Burns ME, Roca A, et al. Rapid and reproducible deactivation of rhodopsin requires multiple phosphorylation sites. Neuron 2000;28:153-64.

109 Maeda T, Imanishi Y, Palczewski K. Rhodopsin phosphorylation: 30 years later. Prog Retin Eye Res 2003;22:417-34.

110 Wilden U, Hall SW, Kuhn H. Phosphodiesterase activation by photoexcited rhodopsin is quenched when rhodopsin is phosphorylated and binds the intrinsic 48-kDa protein of rod outer segments. Proc Natl Acad Sci USA 1986;83:1174-8.

111 Khani SC, Nielsen L, Vogt TM. Biochemical evidence for pathogenicity of rhodopsin kinase mutations correlated with the Oguchi form of congenital stationary night blindness. Proc Natl Acad Sci USA 1998;95:2824-7.

112 Nakamura M, Yamamoto S, Okada M, et al. Novel mutations in the arrestin gene and associated clinical features in Japanese patients with Oguchi's disease. Ophthalmology 2004;111:1410-14.

113 Cideciyan AV, Zhao X, Nielsen L, et al. Null mutation in the rhodopsin kinase gene slows recovery kinetics of rod and cone phototransduction in man. Proc Natl Acad Sci USA 1998;95:328-33.

114 Dryja TP. Molecular genetics of Oguchi disease, fundus albipunctatus, and other forms of stationary night blindness: LVII Edward Jackson Memorial Lecture. Am J Ophthalmol 2000;130:547-63.

115 Nakazawa M, Wada Y, Fuchs S, et al. Oguchi disease: phenotypic characteristics of patients with the frequent 1147 delA mutation in the arrestin gene. Retina 1997:17:17-22.

116 Nakamachi Y, Nakamura M, Fujii S, et al. Oguchi disease with sectoral retinitis pigmentosa harboring adenine deletion at position 1147 in the arrestin gene. Am J Ophthalmol 1998;125:249-51

117 Yoshii M, Murakami A, Akeo K, et al. Visual function and gene analysis in a family with Oguchi's disease. Ophthalmic Res 1998;30:394-401.

118 Maw M, Kumaramanickavel G, Kar B, et al. Two Indian siblings with Oguchi disease are homozygous for an arrestin mutation encoding premature termination. Hum Mutat 1998;1:S317-9.

119 Yamamoto S, Khani SC, Berson EL, et al. Evaluation of the rhodopsin kinase gene in patients with retinitis pigmentosa. Exp Eye Res 1997;65:249-53.

120 Fain GL, Lisman JE. Light, Ca2+, and photoreceptor death: new evidence for the equivalent-light hypothesis from arrestin knockout mice. Invest Ophthalmol Vis Sci 1999:40:2770-2.

121 Sieving PA, Fowler ML, Bush RA, et al. Constitutive "light" adaptation in rods from G90D rhodopsin: a mechanism for human congenital nightblindness without rod cell loss. J Neurosci 2001;21:5449-60.

122 Lem J, Fain GL. Constitutive opsin signaling: night blindness or retinal degeneration? Trends Mol Med 2004;10:150-7.

123 Dryja TP, Berson EL, Rao VR, et al. Heterozygous missense mutation in the rhodopsin gene as a cause of congenital stationary night blindness. Nat Genet 1993:4:280-3.

124 al-Jandal N, Farrar GJ, Kiang AS, et al. A novel mutation within the rhodopsin gene (Thr-94-lle) causing autosomal dominant congenital stationary night blindness. Hum Mutat 1999;13:75-81.

125 Sieving PA, Richards JE, Naarendorp F, et al. Dark-light: model for nightblindness from the human rhodopsin Gly-90-->Asp mutation. Proc Nat Acad Sci USA 1995;92:880-4.

126 Rao VR, Cohen GB, Oprian DD. Rhodopsin mutation G90D and a molecular mechanism for congenital night blindness. Nature 1994;367:639-42.

127 Ramon E, del Valle U, Garriga P. Unusual thermal and conformational properties of the rhodopsin congenital night blindness mutant Thr-94 $\rightarrow$ lle. J Biol Chem 2003;278:6427-32

128 Gross AK, Rao VR, Oprian DD. Characterization of rhodopsin congenital night blindness mutant T94I. Biochemistry 2003;42:2009-15.

129 Jin S, Cornwall MC, Oprian DD. Opsin activation as a cause of congenital night blindness. Nat Neurosci 2003;6:731-5.

130 Jin M, Li S, Moghrabi WN, et al. Rpe65 is the retinoid isomerase in bovine retinal pigment epithelium. Cell 2005;122:449-59. 
131 Moiseyev G, Chen Y, Takahashi Y, et al. RPE65 is the isomerohydrolase in the retinoid visual cycle. Proc Natl Acad Sci USA 2005;102:12413-18

132 Melia TJ Jr, Cowan CW, Angleson JK, et al. A comparison of the efficiency of $G$ protein activation by ligand-free and light-activated forms of rhodopsin. Biophys J 1997:73:3182-91.

133 Van Hooser JP, Liang Y, Maeda T, et al. Recovery of visual functions in a mouse model of Leber congenital amaurosis. J Biol Chem 2002;277:19173-82.

134 Woodruff ML, Wang Z, Chung HY, et al. Spontaneous activity of opsin apoprotein is a cause of Leber congenital amaurosis. Nat Genet 2003;35: 158-64.

135 Ablonczy Z, Crouch RK, Goletz PW, et al. 11-cis-retinal reduces constitutive opsin phosphorylation and improves quantum catch in retinoid-deficien mouse rod photoreceptors. J Biol Chem 2002;277:40491-8.

136 Aleman TS, Jacobson SG, Chico JD, et al. Impairment of the transient pupillary light reflex in Rpe65(-/-) mice and humans with leber congenital amaurosis. Invest Ophthalmol Vis Sci 2004;45:1259-71.

137 Danciger M, Matthes MT, Yasamura D, et al. A QTL on distal chromosome 3 that influences the severity of light-induced damage to mouse photoreceptors. Mamm Genome 2000;1 1:422-7.

138 Stargardt K. Uber familiare, progressive degeneration in der maculagegend des auges. Graefes Arch Ophthalmol 1909:71:534-50.

139 Fishman GA, Stone EM Grover S, et al. Variation of clinical expression in patients with Stargardt dystrophy and sequence variations in the $A B C R$ gene. Arch Ophthalmol 1999; 117:504-10.

140 Eagle RC Jr, Lucier AC, Bernardino VB Jr, et al. Retinal pigment epithelial abnormalities in fundus flavimaculatus: a light and electron microscopic study. Ophthalmology 1980;87:1 189-200.

141 Birnbach CD, Jarvelainen M, Possin DE, et al. Histopathology and immunocytochemistry of the neurosensory retina in fundus flavimaculatus. Ophthalmology 1994;101:1211-9.

142 Sparrow JR, Boulton M. RPE lipofuscin and its role in retinal pathobiology. Exp Eye Res 2005;80:595-606.

143 Cideciyan AV, Aleman TS, Swider M, et al. Mutations in ABCA4 result in accumulation of lipofuscin before slowing of the retinoid cycle: a reappraisal of the human disease sequence. Hum Mol Genet 2004;13:525-34.

144 Allikmets R, Singh N, Sun H, et al. A photoreceptor cell-specific ATP-binding transporter gene $(A B C R)$ is mutated in recessive Stargardt macular dystrophy. Nat Genet 1997;15:236-46.

145 Azarian SM, Travis $G H$. The photoreceptor rim protein is an $A B C$ transporter encoded by the gene for recessive Stargardt's disease (ABCR). FEBS Lett 1997:409:247-52.

146 Illing M, Molday LL, Molday RS. The 220-kDa rim protein of retinal rod outer segments is a member of the $A B C$ transporter superfamily. J Biol Chem 1997;272:10303-10.

147 Sun H, Nathans J. Stargardt's ABCR is localized to the disc membrane of retinal rod outer segments. Nat Genet 1997;17:15-16.

148 Molday LL, Rabin AR, Molday RS. ABCR expression in foveal cone photoreceptors and its role in Stargardt macular dystrophy. Nat Genet 2000;25:257-8.

149 Rozet JM, Gerber S, Souied E, et al. Spectrum of ABCR gene mutations in autosomal recessive macular dystrophies. Eur J Hum Genet 1998:6:291-5.

150 Martinez-Mir A, Paloma E, Allikmets R, et al. Retinitis pigmentosa caused by a homozygous mutation in the Stargardt disease gene ABCR. Nat Genet 1998;18:11-12

151 Cremers FP, van de Pol DJ, van Driel $M$, et al. Autosomal recessive retinitis pigmentosa and cone-rod dystrophy caused by splice site mutations in the Stargardt's disease gene ABCR. Hum Mol Genet 1998;7:355-62.

152 Allikmets R, Shroyer NF, Singh N, et al. Mutation of the Stargardt disease gene (ABCR) in age-related macular degeneration. Science 1997;277:1805-7.
153 Mata NL, Tzekov RT, Liu X, et al. Delayed dark-adaptation and lipofuscin accumulation in abcr+/- mice: implications for involvement of ABCR in agerelated macular degeneration. Invest Ophthalmol Vis Sci 2001;42:1685-90.

154 Stone EM, Webster AR, Vandenburgh K, et al. Allelic variation in $A B C R$ associated with Stargardt disease but not age-related macular degeneration. Nat Genet 1998;20:328-9.

155 Guymer RH, Heon E, Lotery AJ, et al. Variation of codons 1961 and 2177 of the Stargardt disease gene is not associated with age-related macular degeneration. Arch Ophthalmol 2001;119:745-51.

156 Schmidt S, Postel EA, Agarwal A, et al. Detailed analysis of allelic variation in the ABCA4 gene in age-related maculopathy. Invest Ophthalmol Vis Sci 2003;44:2868-75.

157 van Driel MA, Maugeri A, Klevering BJ, et al. $A B C R$ unites what ophthalmologists divide(s). Ophthalmic Genet 1998;19:117-22.

158 Beharry S, Zhong M, Molday RS. N-retinylidene-phosphatidylethanolamine is the preferred retinoid substrate for the photoreceptor-specific $A B C$ transporter ABCA4 (ABCR). J Biol Chem 2004;279:53972-9.

159 Eldred GE, Lasky MR. Retinal age pigments generated by self-assembling lysosomotropic detergents. Nature 1993;361:724-6.

160 Holz FG, Schutt F, Kopitz J, et al. Inhibition of lysosomal degradative functions in RPE cells by a retinoid component of lipofuscin. Invest Ophthalmol Vis Sci 1999;40:737-43.

161 Sparrow JR, Parish CA, Hashimoto M, et al. A2E, a lipofuscin fluorophore, in human retinal pigmented epithelial cells in culture. Invest Ophthalmol Vis Sci 1999;40:2988-95.

162 Sparrow JR, Nakanishi K, Parish CA. The lipofuscin fluorophore A2E mediates blue light-induced damage to retinal pigmented epithelial cells. Invest Ophthalmol Vis Sci 2000;41:1981-9.

163 Suter M, Reme C, Grimm C, et al. Age-related macular degeneration. The lipofusion component $\mathrm{N}$-retinyl-N-retinylidene ethanolamine detaches proapoptotic proteins from mitochondria and induces apoptosis in mammalian retinal pigment epithelial cells. J Biol Chem 2000;275:39625-30.

164 Finnemann SC, Leung LW, Rodriguez-Boulan E. The lipofuscin component A2E selectively inhibits phagolysosomal degradation of photoreceptor phospholipid by the retinal pigment epithelium. Proc Natl Acad Sci USA 2002; 99:3842-7.

165 Sparrow JR, Fishkin N, Zhou J, et al. A2E, a byproduct of the visual cycle. Vis Res 2003;43:2983-90.

166 Weleber RG, Denman ST, Hanifin JM, et al. Abnormal retinal function associated with isotretinoin therapy for acne. Arch Ophthalmol 1986; 104:831-7.

167 Law WC, Rando RR. The molecular basis of retinoic acid induced night blindness. Biochem Biophys Res Commun 1989;161:825-9.

168 Sieving PA, Chaudhry P, Kondo M, et al. Inhibition of the visual cycle in vivo by 13-cis retinoic acid protects from light damage and provides a mechanism for night blindness in isotretinoin therapy. Proc Natl Acad Sci USA 2001 ; 98:1835-40.

169 Radu RA, Mata NL, Nusinowitz S, et al. Treatment with isotretinoin inhibits lipofuscin accumulation in a mouse model of recessive Stargardt's macular degeneration. Proc Natl Acad Sci USA 2003;100:4742-7.

170 Golczak M, Kuksa V, Maeda T, et al. Positively charged retinoids are potent and selective inhibitors of the trans-cis isomerization in the retinoid (visual) cycle. Proc Natl Acad Sci USA 2005; 102:8162-7.

171 Radu RA, Han Y, Bui TV, et al. Reductions in serum vitamin A arrest accumulation of toxic retinal fluorophores: a potential therapy for treatment of lipofuscin-based retinal diseases. Invest Ophthalmol Vis Sci 2005;46:4393-401.

172 Maiti P, Kong J, Kim SR, et al. Small molecule RPE65 antagonists limit the visual cycle and prevent lipofuscin formation. Biochemistry 2006;45:852-60 